\title{
Acute Lung Injury - From Pathophysiology to Treatment
}

\author{
Daniela MOKRA ${ }^{1}$ \\ ${ }^{1}$ Department of Physiology, Jessenius Faculty of Medicine in Martin, Comenius University in \\ Bratislava, Martin, Slovak Republic
}

Received March 30, 2020

Accepted October 13, 2020

\begin{abstract}
Summary
Acute lung injury is characterized by acute respiratory insufficiency with tachypnea, cyanosis refractory to oxygen, decreased lung compliance, and diffuse alveolar infiltrates on chest X-ray. The 1994 American-European Consensus Conference defined "acute respiratory distress syndrome, ARDS" by acute onset after a known trigger, severe hypoxemia defined by $\mathrm{PaO}_{2} / \mathrm{FiO}_{2} \leq 200 \mathrm{~mm} \mathrm{Hg}$, bilateral infiltrates on chest X-ray, and absence of cardiogenic edema. Milder form of the syndrome with $\mathrm{PaO}_{2} / \mathrm{FiO}_{2}$ between $200-300 \mathrm{~mm} \mathrm{Hg}$ was named „acute lung injury, ALI". Berlin Classification in 2012 defined three categories of ARDS according to hypoxemia (mild, moderate, and severe), and the term "acute lung injury" was assigned for general description or for animal models. ALI/ARDS can originate from direct lung triggers such as pneumonia or aspiration, or from extrapulmonary reasons such as sepsis or trauma. Despite growing understanding the ARDS pathophysiology, efficacy of standard treatments, such as lung protective ventilation, prone positioning, and neuromuscular blockers, is often limited. However, there is an increasing evidence that direct and indirect forms of ARDS may differ not only in the manifestations of alterations, but also in the response to treatment. Thus, individualized treatment according to ARDS subtypes may enhance the efficacy of given treatment and improve the survival of patients.
\end{abstract}

\section{Key words}

Acute lung injury - Acute respiratory distress syndrome • Pathophysiology • Therapy • ARDS subtypes

\section{Corresponding author}

D. Mokra, Department of Physiology, Jessenius Faculty of Medicine in Martin, Comenius University in Bratislava,
Mala Hora 4C, SK-03601 Martin, Slovak Republic, E-mail: daniela.mokra@uniba.sk

\section{Introduction}

Acute respiratory distress characterized by tachypnea, cyanosis refractory to oxygen delivery, decreased lung compliance, and diffuse alveolar infiltrates evident on chest X-ray was firstly described in 1967. Within the following decades, definitions of the acute respiratory distress syndrome (ARDS) have several times changed. Regarding improved definitions and more precise diagnostic methods, it has been expected that the prognosis should also improve. However, despite use of lung protective ventilation, neuromuscular blockers, and prone positioning, mortality of this syndrome still remains around $40 \%$.

Nevertheless, there is an increasing evidence that direct (pulmonary) and indirect (extrapulmonary) forms of ARDS may differ not only in the manifestations of lung alterations, but also in the response to treatment. Thus, individualized treatment according to ARDS subtypes may enhance the efficacy of given treatment and improve the survival of patients.

This article provides a review of current knowledge on pathophysiology of ARDS, biomarkers of ARDS as well as on novel treatment approaches which may be of benefit.

\section{Definitions of ARDS}

ARDS was firstly described in 1967 by Ashbaugh and co-workers, who noticed similar 
respiratory symptoms in 12 pacients with acute respiratory failure, which were caused by various triggering factors. Syndrome was resistant to the used treatment and symptoms were similar to symptoms of respiratory distress syndrome (RDS) in premature neonates, suggesting the relation to dysfunction of pulmonary surfactant (Ashbaugh et al. 1967).

Later, the definition and classification criteria of ARDS have changed. In addition, the name of the syndrome has changed from "adult" to "acute" to emphasize that this syndrome may occur in children, as well. In 1994, American-European Consensus Conference postulated the following criteria: a) acute onset of symptoms after a known risk factor with maximum within a week; b) severe hypoxemia resistant to oxygen therapy, with more severe form of respiratory insufficiency defined by a ratio between arterial partial pressure of oxygen and fraction of inspired oxygen $\left(\mathrm{PaO}_{2} / \mathrm{FiO}_{2}\right) \leq 200 \mathrm{~mm} \mathrm{Hg} \quad(26.7 \mathrm{kPa})$ named „ARDS“, and a milder form of this syndrome with $\mathrm{PaO}_{2} / \mathrm{FiO}_{2}$ 200-300 mm Hg (40 kPa) named, ,acute lung injury (ALI)“; c) diffuse bilateral infiltrates on chest X-ray; d) absence of cardiogenic pulmonary edema verified by wedge pressure in the pulmonary artery $\leq 18 \mathrm{~mm} \mathrm{Hg}$ or absence of clinical symptoms of hypertension of the left ventricle (Bernard et al. 1994).

In 2012 in attempt to improve the validity and reliability of the definition, so-called Berlin Classification defined three categories of ARDS according to hypoxemia at a level of positive end-expiratory pressure (PEEP) of $\geq 5 \mathrm{~cm} \mathrm{H}_{2} \mathrm{O}(0.5 \mathrm{kPa})$ : a) mild ARDS with $\mathrm{PaO}_{2} / \mathrm{FiO}_{2}$ between 200-300 mmHg, b) moderate ARDS with $\mathrm{PaO}_{2} / \mathrm{FiO}_{2}$ between $100-200 \mathrm{~mm} \mathrm{Hg}$, and c) severe ARDS with $\mathrm{PaO}_{2} / \mathrm{FiO}_{2} \leq 100 \mathrm{~mm} \mathrm{Hg}$. The category "acute lung injury", which in the previous definition expressed the milder form of ARDS, was omitted from the Berlin definition and this term has been assigned for general description of the situation or for animal models where the clinical definition criteria cannot be fulfilled (ARDS Definition Task Force 2012, Fioretto and de Carvalho 2013).

\section{Epidemiology of ARDS}

Data on incidence of ARDS may largely vary due to several factors including geographical differences and regional genetical variability, differences in health care systems, as well as differences in diagnostic criteria for ARDS (Seeley 2013). For instance, study by
Rubenfeld et al. (2005) found an incidence of mild ARDS of 79/100000 and moderate/severe ARDS of $59 / 100000$ with a total mortality about $40 \%$. However, newer study has shown a declining trend of ARDS incidence in the USA, from incidence of $81 / 100,000$ in 2001 to 38/100,000 in 2008 ( $\mathrm{Li}$ et al. 2010). In recent multicenter prospective study carried out in 459 ICUs in 50 countries in 5 continents, ARDS represented $10.4 \%$ of total admission to intensive care unit (ICU) and $23.4 \%$ of all patients requiring mechanical ventilation. The prevalence was $30.0 \%$ for mild ARDS, $46.6 \%$ for moderate ARDS, and $23.4 \%$ for severe ARDS, and overall, unadjusted ICU and hospital mortality was 35.3 and $40.0 \%$, respectively and both augmented with increased ARDS severity (Bellani et al. 2016).

Except of mortality, long-term consequences in pacients who had survived ARDS in terms of substantial reduction in health-related quality of life and physical and mental dysfunction of a various extent should be taken into account, as well. While most patients may return to normal or near-normal lung physiology, they may exhibit marked and persistent muscle weakness with reduced determinants of functional status (reduced distance walked in $6 \mathrm{~min}$ etc.), higher occurrence of polyneuropathy, myopathy, tracheal stenosis, contractures, sensorineural hearing loss, but also higher occurance of depression, anxiety and post-traumatic stress disorder, and significant cognitive impairment in executive function, memory, and attention, social isolation etc. (Herridge et al. 2016, Bein et al. 2018).

\section{Etiology of ARDS}

ARDS has been defined by exposure to a known direct (pulmonary) or indirect (extrapulmonary) insult or worsening of respiratory symptoms within 7 days. The most common cause of direct ARDS is pneumonia and of indirect ARDS sepsis. However, other factors may also contribute to the pathogenesis of ARDS. Very important seem to be genetic factors with more than 40 candidate genes associated with ARDS (Liu and Li 2014), among which the angiotensin-converting enzyme (ACE) gene-2 protein contributing to regulation of pulmonary vascular permeability was identified as the cell entry receptor for coronavirus that recently caused severe acute respiratory distress syndrome (SARS-CoV) (Kuba et al. 2005). In the context of actual COVID-19 pandemic, expression of ACE2 receptors and treatment with ACE2-increasing drugs in relation to the risks and prognosis of 
SARS-CoV-2 infection have been intensively studied (Fang et al. 2020, Milne et al. 2020, Aronson and Ferner 2020).

Additional factors increasing the risk of ARDS are e.g. virulence factors, race differences, environmental factors (chronic alcohol abuse, cigarette smoke exposure), older age ( $>65$ years), chronic lung disease, concomittant diseases etc. (Matthay et al. 2012, Spadaro et al. 2019). Development and worsening of ARDS can be potentiated by inappropriate mechanical ventilation where the ventilator-induced lung injury can be caused by excessive lung stretch (volutrauma) or pressure (barotrauma), repetitive alveolar opening and closing, leading to shearing injury (atelectrauma), and potential oxygen toxicity. These changes also trigger systemic inflammation, potentially inducing extra-pulmonary organ failure (biotrauma) (Sweeney and McAuley 2016).

Table 1. The most frequent risk factors of ARDS (Ware and Matthay 2000, Mortelliti and Manning 2002, Saharan et al. 2010).

Risk factors of ARDS

Direct lung injury

\begin{tabular}{cc}
\hline Pneumonia & Sepsis \\
Aspiration of gastric content & Severe trauma with shock \\
Lung contusion & Repetitive blood transfusion \\
Fat embolism & Acute pancreatitis \\
Near-drowning & Drug abuse \\
Inhalation injury (smoke, gases) & Burns \\
Reperfusion edema after lung transplantation or lung & Disseminated intravascular coagulation (DIC) \\
\hline
\end{tabular}

\section{Pathogenesis of ARDS}

Acute, exudative phase (0-7 days) is characterized by rapid onset of respiratory dysfunction. Tachypnoea, tachycardia and respiratory alkalosis, which may precede a finding of diffuse bilateral infiltrates on $\mathrm{X}$-ray, may occur within first $12-24 \mathrm{~h}$ after initiating insult. These findings are associated with diffuse alveolar damage with destruction of epithelial-endothelial barrier, allowing excessive leak of protein-rich fluid and blood cells into the interstitium and alveoli (Ware and Matthay 2000, Matthay et al. 2012). Tissue injury triggers transmigration of neutrophils which are activated and together with alveolar macrophages, platelets and other inflammatory and fixed lung cells produce a wide variety of substances which exacerbate inflammation but can also serve as biomarkers of acute phase (see further).

Damage of surfactant-producing alveolar type II cells and inactivation of surfactant layer in the alveoli by edematous plasma proteins and pro-inflammatory cytokines lead to alveolar atelectasis and decreased lung compliance. The loss of function of epithelial ion channels impairs the generation of osmotic forces necessary to return edema fluid from alveoli to the interstitium. These changes together with development of hyaline membranes from leaking plasma proteins, alveolar hemorrhage, and decreased pulmonary compliance result in worsening of the gas exchange. Besides contribution to increased permeability, alveolar vascular damage is associated with altered vasomotor tone (both vasoconstriction and vasodilation) and formation of microthrombi. Increasing right ventricular afterload results into pulmonary hypertension. The right ventricular dysfunction can be further exacerbated by inappropriate mechanical ventilation and fluid overload. Combined epithelial and endothelial damage finally end up in worsening ventilation-perfusion mismatch and refractory hypoxia (Mortelliti and Manning 2002, Sweeney and McAuley 2016). Nevertheless, the mechanisms by which the microvascular endothelium and alveolar epithelium are injured can be more complex and may vary depending on the triggering pulmonary or extrapulmonary event (Spadaro et al. 2019).

Within 5-7 days from the insult, the exudative phase fluently converts to the proliferative phase, which is characterized by proliferation and fenotypic changes of fibroblasts and alveolar cells type II, differentiating into type I alveolar cells. Regeneration of epithelial layer 
permits the clearance of edematous liquid from the lung, and the remaining intraalveolar debris is also cleared by inflammatory cells, particularly by macrophages. As reparation continues, restoration of vasomotor tone reduces the shunts, and gradually decreasing pulmonary hypertension leads to improved oxygenation that is followed by recovering lung compliance. In some patients the proliferative phase may progress into the fibrotic phase, which is associated with diffuse fibrotic changes of the lung tissue due to failure of removal of alveolar collagen (Ware and Matthay 2000, Matthay et al. 2012, Bhargava and Wendt 2012). However, fibroproliferative changes may develop sooner, as indicated by evidence of collagen synthesis as early as $24 \mathrm{~h}$ of the course of ARDS, thus, may be initiated simultaneously with inflammatory changes (Marshall et al. 2000, Spadaro et al. 2019).

\section{Clinically relevant biomarkers of ARDS}

In relation to the above-mentioned changes, various biologically active substances are produced or released from damaged cells in high concentrations. Many of them may serve as biomarkers providing information for identification of patients at risk for ARDS, progression of the lung injury, response to treatment, or prognosis. Several biomarkers for exudative and proliferative (or fibroproliferative) phases of ARDS have been investigated in the blood, pulmonary edema fluid or bronchoalveolar lavage fluid (BALF), and exhaled air. However, while none of them is reliable enough if considered alone, combinations of biomarkers are recommended. Lists of the most important biomarkers of exudative and fibroproliferative phases of ARDS are provided in Table 2 and Table 3.

Table 2. Biomarkers of acute (exudative) phase of ARDS (Bhargava and Wendt 2012, Fujishima 2014, Hussain et al. 2018).

\begin{tabular}{|c|c|c|c|}
\hline & Marker & $\begin{array}{c}\text { Biological source of } \\
\text { biomarker }\end{array}$ & Change in ARDS \\
\hline Alveolar cells type I & sRAGE & Plasma, BALF & $\uparrow$ \\
\hline \multirow{2}{*}{ Alveolar cells type II } & SP-A, SP-B, SP-D & Plasma, BALF & $\downarrow$ BALF, $\uparrow$ plasma \\
\hline & KL-6 & Plasma, BALF & $\uparrow$ \\
\hline Non-ciliary bronchial cells & $\mathrm{CC} 16$ & Plasma, BALF & $\uparrow$ \\
\hline \multirow{3}{*}{ Extracellular matrix } & Laminin & Plasma, BALF & $\uparrow$ \\
\hline & Elastin/Desmosin & Urine & $\uparrow$ \\
\hline & MMPs & Plasma, BALF & $\uparrow$ \\
\hline \multirow{5}{*}{ Endothelial cells } & Angiopoietin-2 & Plasma & $\uparrow$ \\
\hline & sP-selectin & Plasma & $\uparrow$ \\
\hline & sICAM-1 & Plasma & $\uparrow$ \\
\hline & vWF & Plasma & $\uparrow$ \\
\hline & Thrombomodulin & Plasma & $\uparrow$ \\
\hline \multirow{3}{*}{ Coagulation } & PAI-1 & Plasma & $\uparrow$ \\
\hline & protein $\mathrm{C}$ & Plasma & $\downarrow$ \\
\hline & vWF & Plasma & $\uparrow$ \\
\hline \multirow{4}{*}{ Inflammation } & IL-1 $\beta$, IL-6, IL-8, & Plasma, BALF & $\uparrow$ \\
\hline & IL-10 & Plasma, BALF & $\uparrow$ \\
\hline & $\mathrm{TNF} \alpha$ & Plasma, BALF & $\uparrow$ \\
\hline & CRP & Plasma & $\uparrow$ \\
\hline
\end{tabular}

BALF: bronchoalveolar lavage fluid; CC16: Club cell protein; CRP: C-reactive protein; IL: interleukin; KL: Krebs von den Lungen protein; PAI: plasminogen activator inhibitor; sICAM: soluble intercellular adhesion molecule; SP: specific surfactant protein; sRAGE: soluble receptor for advanced glycation end products; vWF: von Willebrand factor; TNF: tumor necrosis factor; MMPs: matrix metalloproteinases; SP-selectin: soluble P-selectin. 
Table 3. Biomarkers of late (fibroproliferative) phase of ARDS (Bhargava and Wendt 2012, Fujishima 2014, Hussain et al. 2018).

\begin{tabular}{lccc}
\hline & Marker & $\begin{array}{c}\text { Biological source of } \\
\text { biomarker }\end{array}$ & Change in ARDS \\
\hline \multirow{2}{*}{ Proliferation of epithelium } & KGF & BALF & $\uparrow$ \\
& HGF & BALF & $\uparrow$ \\
\hline \multirow{2}{*}{ Proliferation of endothelium } & VEGF & Plasma, BALF & $\uparrow$ plasma, $\downarrow$ BALF \\
& Angiopoietin-2 & Plasma & $\uparrow$ \\
\hline Apoptosis of epithelial cells & Fas/FasL & BALF & $\uparrow$ \\
\hline Proliferation of fibroblasts & N-PCP-III & BALF & $\uparrow$ \\
\hline
\end{tabular}

BALF: bronchoalveolar lavage fluid, KGF: keratinocyte growth factor; HGF: hepatocyte growth factor; VEGF: vascular endothelial growth factor; N-PCP-III: N-terminal procollagen peptide-III.

\section{ARDS subphenotypes}

\section{Direct $v$ s. indirect lung injury groups}

According to molecular phenotyping, direct and indirect ARDS phenotypes have been described (Calfee et al. 2015). In direct lung injury, noxious stimulus hits primarily the lung structures. Activation of innate immune response by binding of bacterial products or cellinjury associated endogenous molecules (dangerassociated molecular patterns, DAMPs) to pattern recognition receptors (e.g. Toll-like receptors) on the lung epithelium and alveolar macrophages initiates the acute inflammatory response (Matthay et al. 2012). In addition, neutrophil extracellular traps (NETs), extracellular histones, and granular proteins (e.g. neutrophil elastase and myeloperoxidase) released from dying neutrophils also act as DAMPs and induce epithelial and endothelial cell death. When enter the circulation, histones stimulate platelet aggregation, enhance recruitment of neutrophils, and aggravate inflammation (Xu et al. 2015, Lv et al. 2017). Extensive activation of leukocytes can progress to systemic inflammatory response syndrome (SIRS), multiple organ dysfunction syndrome (MODS), and multiple organ failure (Bhatia and Moochhala 2004).

If the primary cause of ARDS is located in extrapulmonary tissues, the lung inflammation and edema generation may be triggered by high concentrations of histones to which is the lung highly susceptible (Abrams et al. 2013, Xu et al. 2015). However, other substances including pro-inflammatory cytokines TNF $\alpha$ and IL-1 $\beta$, high-mobility group box (HMGB)-1 protein, or mitochondrial deoxyribonucleic acid (DNA) can also act as DAMPs and induce lung inflammation and ARDS (Fujishima 2014).
Nevertheless, there are additional differences between the direct and indirect ARDS, as well. In the direct form of ARDS, the injury is more localized to alveolar epithelial cells, with alveolar collapse, accumulation of neutrophils, fibrin deposition, and formation of hyaline membranes and alveolar wall edema. In the indirect ARDS, diffuse injury to endothelial cells is prominent, with typical finding of interstitial edema and less obvious lung accumulation of neutrophils than in the direct form.

The substances released from injured lung cells or produced by activated cells spill over into the blood and thereby can serve as valuable biomarkers of ARDS reflecting damage to specific cells and dynamics of the process (Bhargava and Wendt 2012, Mokra and Kosutova 2014). In the direct ARDS, concentrations of TNF $\alpha$, IL-1 $\beta$, IL-6, and IL-8 elevate mainly in the bronchoalveolar lavage fluid (BALF) or lung tissue. Because of primary injury to epithelial cells, surfactant protein (SP)-D as a valuable marker of type II alveolar cells injury and receptor for advanced glycation end products (RAGE) as a marker of type I alveolar cells injury have been identified. In the indirect ARDS, increased proinflammatory cytokines are detected predominantly in the plasma indicating that the lung injury is caused by the action of mediators released from extrapulmonary foci into the systemic circulation (Pelosi et al. 2003, Shaver and Bastarache 2014). Damage of endothelial cells and prominent systemic inflammation can be confirmed by elevated plasma levels of von Willebrand factor (vWF), IL-6, IL-8, and angiopoietin-2 (Bhargava and Wendt 2012, Calfee et al. 2015).

It has been shown that the differences in the pathomechanisms of ARDS of pulmonary and 
extrapulmonary origins may influence the efficacy of the used therapeutic strategies, as well (Pelosi et al. 2003, Rocco and Pelosi 2008). In animal models, methylprednisolone more effectively attenuated the inflammatory changes, lung mechanics and morphometrics in a model of direct ARDS (Leite-Junior et al. 2008), while response to recruitment maneuvers and PEEP on oxygenation and lung mechanics was better in a model of indirect ARDS (Kloot et al. 2000). The first clinical data indicate that the epithelium could be a treatment target with keratinocyte growth factor (KGF) for direct ARDS, whereas the endothelium could be targeted in indirect ARDS using statins and recombinant angiopoietin 1 (Calfee et al. 2015). Thus, the above-mentioned specific combinations of biomarkers not only help to distinguish patients with direct ARDS from those with an indirect ARDS, but may also help in the diagnosis and identification of patients who may benefit from different therapeutic strategies (Spadaro et al. 2019).

\section{Hyperinflammatory vs. hypoinflammatory groups}

According to their clinical and biological characteristics and response to treatment, hyperinflammatory and hypoinflammatory subphenotypes have been described (Calfee et al. 2014, Reilly et al. 2014, Calfee et al. 2015). The hyperinflammatory phenotype, covering about one third of ARDS patients, is associated with higher plasma levels of IL-6, IL-8, soluble tumor necrosis factor receptor (sTNFR)-1, and plasminogen activator inhibitor (PAI)-1 and lower protein $\mathrm{C}$, worse metabolic acidosis with lower serum bicarbonate, higher vasopressor requirements, higher prevalence of sepsis, fewer ventilator-free and organ failure-free days, and increased mortality. Among the biomarkers, IL-6, interferon gamma (IFN- $\gamma$ ), angiopoietin 1/2 and PAI-1 have been identified to cluster ARDS into two biological phenotypes with different mortality rates (Bos et al. 2017), and different responses to PEEP (Calfee et al. 2014) and fluid management strategies (Famous et al. 2017).

\section{Other promising biomarkers}

\section{Metabolomics}

There is an increasing number of publications demonstrating that the analysis of lower molecular weight cell metabolites (metabolomics), which is generally performed using nuclear magnetic resonance (NMR) and mass spectrometry (MS), may bring additional information for diagnosis and treatment of ARDS and/or sepsis (Stringer et al. 2016, Eckerle et al. 2017). Investigation of metabolic changes may be useful for detection of physiological changes in real time allowing monitoring of potential insults, disease progression and drug responses, while these changes occur in relation to alterations in the gene and protein activity, which are associated with the disease (Stringer et al. 2016). Metabolomics studies performed in experimental models as well as in patients with ARDS analysed a variety of samples from exhaled breath, serum, BALF and lung tissue and found that the lung injury results in a perturbation of energy and oxidative stress metabolism (Evans et al. 2014, Stringer et al. 2016, Viswan et al. 2017, Bos 2018, Viswan et al. 2019).

\section{MicroRNA (MiRNA)}

MiRNA, non-coding RNA molecules which regulate gene expression at the post-transcriptional level, play an important role in inflammation and/or apoptosis in ARDS (Ferruelo et al. 2018). They can serve as useful biomarkers because of their easy identification in various body fluids, resistance to environmental conditions, and changes of expression in various disease states (CardinalFernández et al. 2016). Recently, many circulating miRNAs (miR-25, miR-133a, miR-146, miR-150, miR-223 etc.) were found to be associated with various pathological conditions, such as inflammation, infection, and sepsis, while some of them correlated well with the disease stage, and patients' short and long term prognosis (Benz et al. 2016).

In ARDS patients, three whole blood miRNA markers (miR-181a, miR92a and miR-424) were significantly associated with ARDS, with miR-181a and miR-92a as risk biomarkers for ARDS and miR-424 as a protective biomarker (Zhu et al. 2017).

\section{Treatment of ARDS}

Despite understanding the pathophysiology of ALI/ARDS has greatly improved within the last decades, mortality remains high and efficacy of standard therapeutic approaches is limited.

\section{Non-pharmacological interventions}

The currently used therapy is based on so-called lung-protective mechanical ventilation. The ventilation protecting the lung from additional ,,ventilator-induced lung injury (VILI)“ should: 1) use low tidal volumes 
( $<6 \mathrm{ml} / \mathrm{kg}$ of the predicted body weight) combined with limited inspiratory plateau pressures $\left(<30 \mathrm{~cm} \mathrm{H}_{2} \mathrm{O}\right)$ to prevent a lung overdistension ("barotrauma/volutrauma"); 2) use sufficiently high levels of PEEP to prevent a repetitive opening and closing of the terminal lung units ("atelectrauma") (Haberthür and Seeberger 2016, Umbrello et al. 2017).

For re-inflation of the collapsed lung regions, different types of recruitment maneuvers, such as sustained inflation, intermittent sighs and stepwise increase in inspiratory pressure could be of benefit, however, their use is discussed (Chiumello et al. 2016).

Some improvement may bring the highfrequency oscillatory ventilation (HFOV) which uses very small tidal volumes $(2 \mathrm{ml}$ per $\mathrm{kg}$ of predicted body weight) at high frequencies of up to 900 breaths per min, via several atypical mechanisms of gas transfer (Sweeney and McAuley 2016). However, two large randomised controlled trials failed to show any benefit from this mode of ventilation in adults with ARDS (Ferguson et al. 2013, Young et al. 2013).

When mechanical ventilation is unable to provide an adequate gas exchange because a critical volume of alveolar units has failed, extracorporeal membrane oxygenation (ECMO) can be used as a lifesaving respiratory support. ECMO replaces endogenous alveolar gaseous exchange, allows reduction in ventilatory settings, and reduces the risk of VILI (Sweeney and McAuley 2016). Use of ECMO in refractory hypoxemia (Peek et al. 2009) may improve survival, however, is limited to the specialized centers.

Other approach with favorable results is prone positioning which should be reserved to patients with severe ARDS, especially in the acute phase (Lichtenstein and Mezière 2008, Umbrello et al. 2017). Because of ability to recruit lung parenchyma this approach enables better ventilation/perfusion matching with a consequent improvement in clearance of carbon dioxide, more homogenous distribution of ventilation with a reduction of VILI and recruitment of dorsal lung regions through the redistribution of lung densities (Gattinoni et al. 2013, Guérin and Mancebo 2015).

In 2017, guidelines on the above-mentioned interventions were summarized in the International Clinical Practice Guideline for mechanical ventilation on adults with ARDS (Fan et al. 2017).

Conservative fluid management is an essential aspect of therapy since pulmonary edema is a main feature of ARDS. Fluid excess is linked to hemodynamic instability, decreased oxygenation and worsening lung injury scores. On the other hand, the conservative fluid management enhanced lung function and shortened the duration of mechanical ventilation and intensive care (Wiedemann et al. 2006), and may also decrease mortality (Semler et al. 2016).

\section{Pharmacotherapy}

Within the last decades, several groups of medicaments have been used for pharmacotherapy of ARDS, however, a positive response to some of them has been shown just in specific subgroups of patients (Boyle et al. 2013, Standiford and Ward 2016).

Among the pharmacological interventions, use of neuromuscular blocking agents (NMBAs) seems to be the most promising. As spontaneous breathing in the patients with severe ARDS might generate high transpulmonary pressure, use of NMBAs enables amelioration of patient-ventilator synchrony in reduced oxygen consumption leading to improved survival (Neto et al. 2012, Hraiech et al. 2015). However, data from recent meta-analyses bring inconsistent information on the lung function or mortality (Hua et al. 2020, Zheng et al. 2020).

Because of their potent anti-inflammatory and antiedematous actions, corticosteroids have been tested in experimental models of acute lung injury (Mokra et al. 2013, Mokra et al. 2016, Kosutova et al. 2016, Mikolka et al. 2019) where they significantly reduced inflammation, edema formation, and oxidative stress. Promising is also combination of corticosteroids with exogenous surfactant (Mikolka et al. 2013, Mikolka et al. 2016). In patients with ARDS, some improvements in duration of mechanical ventilation, duration of hospitalization or oxygenation have been observed for low-to-moderate dose of corticosteroids, if administered early (<14 days from insult) (Tongyoo et al. 2016, Meduri et al. 2018). However, if steroids are started 14 days or more after the diagnosis of ARDS, they can be even harmful (Steinberg et al. 2006, Mokra et al. 2019). The combination of inhaled $\beta_{2}$-agonists and corticosteroid (formoterol/budesonide) administered early in patients at risk of ARDS has prevented development of ARDS and improved oxygenation (Festic et al. 2017).

Beneficial could be phosphodiesterase (PDE) inhibitors exerting a wide spectrum of actions including anti-inflammatory, antioxidant and antiedematous effects. In experimental models of ARDS, treatment with both non-selective and selective PDE-3, PDE-4 or PDE-5 
inhibitors led to significant improvement of lung functions and to reduced inflammation (Fakioglu et al. 2004, Mokra et al. 2008, Mokra et al. 2012, Schick et al. 2012, Kosutova et al. 2018a, Kosutova et al. 2018b). However, there are only few clinical studies on the use of PDE inhibitors, with questionable results (Salari et al. 2005, Cornet et al. 2010).

Pre-treatment with aspirin decreased the incidence of ARDS (Boyle et al. 2015), however, the recent data are inconsistent (Wang et al. 2018, Du et al. 2018). Inhaled nitric oxide (NO) transiently improved oxygenation and long-term lung function in ARDS survivors, but without effect on mortality, and because of risk of renal impairment, this treatment is not recommended (Gebistorf et al. 2016). Similarly, many other treatments (statins, beta-agonists, non-steroidal antiinflammatory drugs, antioxidants, exogenous surfactant, neutrophil elastase inhibitors, anticoagulants, anti-TNF biologics etc.) with favorable pre-clinical results failed in the clinical trials (Spadaro et al. 2019). With respect to the lung regeneration, cell therapies and intravenous mesenchymal stem cell therapy have been under intensive research in ARDS (Wilson et al. 2015, Silva et al. 2019, Abraham and Krasnodembskaya 2020).

Nowadays, there is a significant trend to use anti-inflammatory therapies according to ARDS subtyping defined by blood biomarker levels, where the anti-inflammatory agents are expected to be more efficient in patients with hyperinflammatory phenotype of ARDS (Thompson et al. 2017, Meyer and Calfee 2017).

\section{Conclusions}

ARDS is a life-threatening syndrome with extreme heterogeneity. Despite intensive investigation in this field, there is no specific pharmacotherapy for ARDS up to now with significant and uniform effect on the disease development and mortality, although the preclinical trials have demonstrated promising results. Due to complexity of the pathomechanisms involved in ARDS, targeting a single pathogenetic pathway is not an effective way. Nevertheless, subphenotyping of ARDS patients according to blood biomarkers and clinical features may help clinicians to select patients who may benefit from specific therapeutic strategies and ultimately tailor the treatment for individual patients.

\section{Conflict of Interest}

There is no conflict of interest.

\section{Acknowledgements}

This work was supported by projects APVV-15-0075 and VEGA 1/0356/18.

\section{References}

ABRAHAM A, KRASNODEMBSKAYA A: Mesenchymal stem cell-derived extracellular vesicles for the treatment of acute respiratory distress syndrome. Stem Cells Transl Med 9: 28-38, 2020. https://doi.org/10.1002/sctm.19-0205

ABRAMS ST, ZHANG N, MANSON J, LIU T, DART C, BALUWA F, WANG SS, BROHI K, KIPAR A, YU W, WANG G, TOH CH: Circulating histones are mediators of trauma-associated lung injury. Am J Respir Crit Care Med 187: 160-169, 2013. https://doi.org/10.1164/rccm.201206-1037OC

ARDS DEFINITION TASK FORCE, RANIERI VM, RUBENFELD GD, THOMPSON BT, FERGUSON ND, CALDWELL E, FAN E, CAMPOROTA L, SLUTSKY AS: Acute respiratory distress syndrome: The Berlin definition. JAMA 307: 2526-2533, 2012. https://doi.org/10.1001/jama.2012.5669

ARONSON JK, FERNER RE. Drugs and the renin-angiotensin system in covid-19. BMJ 369: m1313, 2020. https://doi.org/10.1136/bmj.m1313

ASHBAUGH DG, BIGELOW DB, PETTY TL, LEVINE BE: Acute respiratory distress in adults. Lancet 2: 319-323, 1967. https://doi.org/10.1016/S0140-6736(67)90168-7

BEIN T, WEBER-CARSTENS S, APFELBACHER C: Long-term outcome after the acute respiratory distress syndrome: different from general critical illness? Curr Opin Crit Care 24: 35-40, 2018. https://doi.org/10.1097/MCC.0000000000000476

BELLANI G, LAFFEY JG, PHAM T, FAN E, BROCHARD L, ESTEBAN A, GATTINONI L, VAN HAREN F, LARSSON A, MCAULEY DF, RANIERI M, RUBENFELD G, THOMPSON BT, WRIGGE H, SLUTSKY AS, PESENTI A; LUNG SAFE INVESTIGATORS; ESICM TRIALS GROUP: Epidemiology, patterns of care, and mortality for patients with acute respiratory distress syndrome in intensive care units in 50 countries. JAMA 315: 788-800, 2016. https://doi.org/10.1001/jama.2016.0291 
BENZ F, ROY S, TRAUTWEIN C, RODERBURG C, LUEDDE T: Circulating microRNAs as biomarkers for sepsis. Int J Mol Sci 17: pii: E78, 2016. https://doi.org/10.3390/ijms17010078

BERNARD GR, ARTIGAS A, BRIGHAM KL, CARLET J, FALKE K, HUDSON L, LAMY M, LEGALL JR, MORRIS A, SPRAGG R; THE AMERICAN-EUROPEAN CONSENSUS CONFERENCE ON ARDS: Definitions, mechanisms, relevant outcomes, and clinical trial coordination. Am J Respir Crit Care Med 149: 818-824, 1994. https://doi.org/10.1164/ajrccm.149.3.7509706

BHARGAVA M, WENDT CH: Biomarkers in acute lung injury. Transl Res 159: 205-217, 2012. https://doi.org/10.1016/j.trsl.2012.01.007

BHATIA M, MOOCHHALA S: Role of inflammatory mediators in the pathophysiology of acute respiratory distress syndrome. J Pathol 202: 145-156, 2004. https://doi.org/10.1002/path.1491

BOS LD, SCHOUTEN LR, VAN VUGHT LA, WIEWEL MA, ONG DSY, CREMER O, ARTIGAS A, MARTINLOECHES I, HOOGENDIJK AJ, VAN DER POLL T, HORN J, JUFFERMANS N, CALFEE CS, SCHULTZ MJ, MARS CONSORTIUM: Identification and validation of distinct biological phenotypes in patients with acute respiratory distress syndrome by cluster analysis. Thorax 72: 876-883, 2017. https://doi.org/10.1136/thoraxjnl-2016-209719

BOS LDJ: Diagnosis of acute respiratory distress syndrome by exhaled breath analysis. Ann Transl Med 6: 33, 2018. https://doi.org/10.21037/atm.2018.01.17

BOYLE AJ, DI GANGI S, HAMID UI, MOTTRAM LJ, MCNAMEE L, WHITE G, CROSS LJ, MCNAMEE JJ, O'KANE CM, MCAULEY DF: Aspirin therapy in patients with acute respiratory distress syndrome (ARDS) is associated with reduced intensive care unit mortality: a prospective analysis. Crit Care 19: 109, 2015. https://doi.org/10.1186/s13054-015-0846-4

BOYLE AJ, SWEENEY RM, MCAULEY DF: Pharmacological treatments in ARDS; a state-of-the-art update. BMC Med 11: 166, 2013. https://doi.org/10.1186/1741-7015-11-166

CALFEE CS, DELUCCHI K, PARSONS PE, THOMPSON BT, WARE LB, MATTHAY MA; THE NHLBI ARDS NETWORK: Subphenotypes in acute respiratory distress syndrome: latent class analysis of data from two randomised controlled trials. Lancet Respir Med 2: 611-620, 2014. https://doi.org/10.1016/S2213$\underline{2600(14) 70097-9}$

CALFEE CS, JANZ DR, BERNARD GR, MAY AK, KANGELARIS KN, MATTHAY MA, WARE LB: Distinct molecular phenotypes of direct vs indirect ARDS in single-center and multicenter studies. Chest 147: 1539-1548, 2015. https://doi.org/10.1378/chest.14-2454

CARDINAL-FERNÁNDEZ P, FERRUELO A, ESTEBAN A, LORENTE JA: Characteristics of microRNAs and their potential relevance for the diagnosis and therapy of the acute respiratory distress syndrome: from bench to bedside. Transl Res 169: 102-111, 2016. https://doi.org/10.1016/j.trsl.2015.11.004

CHIUMELLO D, ALGIERI I, GRASSO S, TERRAGNI P, PELOSI P: Recruitment maneuvers in acute respiratory distress syndrome and during general anesthesia. Minerva Anestesiol 82: 210-220, 2016.

CORNET AD, HOFSTRA JJ, SWART EL, GIRBES AR, JUFFERMANS NP: Sildenafil attenuates pulmonary arterial pressure but does not improve oxygenation during ARDS. Intensive Care Med 36: 758-764, 2010. https://doi.org/10.1007/s00134-010-1754-3

DU F, JIANG P, HE S, SONG D, XU F: Antiplatelet therapy for critically ill patients: a pairwise and Bayesian network meta-analysis. Shock 49: 616-624, 2018. https://doi.org/10.1097/SHK.0000000000001057

DUSHIANTHAN A, GROCOTT MP, POSTLE AD, CUSACK R: Acute respiratory distress syndrome and acute lung injury. Postgrad Med J 87: 612-622, 2011. https://doi.org/10.1136/pgmj.2011.118398

ECKERLE M, AMBROGGIO L, PUSKARICH MA, WINSTON B, JONES AE, STANDIFORD TJ, STRINGER KA: Metabolomics as a driver in advancing precision medicine in sepsis. Pharmacotherapy 37: 1023-1032, 2017. https://doi.org/10.1002/phar.1974

EVANS CR, KARNOVSKY A, KOVACH MA, STANDIFORD TJ, BURANT CF, STRINGER KA: Untargeted LC-MS metabolomics of bronchoalveolar lavage fluid differentiates acute respiratory distress syndrome from health. J Proteome Res 13: 640-649, 2014. https://doi.org/10.1021/pr4007624 
FAKIOGLU H, GELVEZ J, TORBATI D, GLOVER ML, OLARTE JL, CAMACHO MT, WOLFSDORF J: Aminophylline therapy during endotoxemia in anesthetized spontaneously breathing rats. Pharmacol Res 49: 45-50, 2004. https://doi.org/10.1016/j.phrs.2003.03.001

FAMOUS KR, DELUCCHI K, WARE LB, KANGELARIS KN, LIU KD, THOMPSON BT, CALFEE CS; ARDS NETWORK: Acute respiratory distress syndrome subphenotypes respond differently to randomized fluid management strategy. Am J Respir Crit Care Med 195: 331-338, 2017. https://doi.org/10.1164/rccm.201603$\underline{06450 \mathrm{C}}$

FAN E, DEL SORBO L, GOLIGHER EC, HODGSON CL, MUNSHI L, WALKEY AJ, ADHIKARI NKJ, AMATO MBP, BRANSON R, BROWER RG, FERGUSON ND, GAJIC O, GATTINONI L, HESS D, MANCEBO J, MEADE MO, MCAULEY DF, PESENTI A, RANIERI VM, RUBENFELD GD, ET AL.: An Official American Thoracic Society/European Society of Intensive Care Medicine/Society of Critical Care Medicine Clinical Practice Guideline: Mechanical Ventilation in Adult Patients with Acute Respiratory Distress Syndrome. Am J Respir Crit Care Med 195: 1253-1263, 2017. https://doi.org/10.1164/rccm.201703-0548ST

FANG L, KARAKIULAKIS G, ROTH M: Are patients with hypertension and diabetes mellitus at increased risk for COVID-19 infection? Lancet Respir Med 8: e21, 2020. https://doi.org/10.1016/S2213-2600(20)30116-8

FERGUSON ND, COOK DJ, GUYATT GH, MEHTA S, HAND L, AUSTIN P, ZHOU Q, MATTE A, WALTER SD, LAMONTAGNE F, GRANTON JT, ARABI YM, ARROLIGA AC, STEWART TE, SLUTSKY AS, MEADE MO; OSCILLATE TRIAL INVESTIGATORS; CANADIAN CRITICAL CARE TRIALS GROUP: High-frequency oscillation in early acute respiratory distress syndrome. N Engl J Med 368: 795-805, 2013. https://doi.org/10.1056/NEJMoa1215554

FERRUELO A, PEÑUELAS Ó, LORENTE JA: MicroRNAs as biomarkers of acute lung injury. Ann Transl Med 6: 34, 2018. https://doi.org/10.21037/atm.2018.01.10

FESTIC E, CARR GE, CARTIN-CEBA R, HINDS RF, BANNER-GOODSPEED V, BANSAL V, ASUNI AT, TALMOR D, RAJAGOPALAN G, FRANK RD, GAJIC O, MATTHAY MA, LEVITT JE: Randomized clinical trial of a combination of an inhaled corticosteroid and Beta agonist in patients at risk of developing the acute respiratory distress syndrome. Crit Care Med 45: 798-805, 2017. https://doi.org/10.1097/CCM.0000000000002284

FIORETTO JR, DE CARVALHO WB: Temporal evolution of acute respiratory distress syndrome definitions. J Pediatr (Rio J) 89: 523-530, 2013. https://doi.org/10.1016/j.jpedp.2013.02.009

FUJISHIMA S: Pathophysiology and biomarkers of acute respiratory distress syndrome. J Intensive Care 2: 32, 2014. https://doi.org/10.1186/2052-0492-2-32

GATTINONI L, TACCONE P, CARLESSO E, MARINI JJ: Prone position in acute respiratory distress syndrome. Rationale, indications, and limits. Am J Respir Crit Care Med 188: 1286-1293, 2013. https://doi.org/10.1164/rccm.201308-1532CI

GEBISTORF F, KARAM O, WETTERSLEV J, AFSHARI A: Inhaled nitric oxide for acute respiratory distress syndrome (ARDS) in children and adults. Cochrane Database Syst Rev 2016: CD002787, 2016. https://doi.org/10.1002/14651858.CD002787.pub3

GUÉRIN C, MANCEBO J: Prone positioning and neuromuscular blocking agents are part of standard care in severe ARDS patients: yes. Intensive Care Med 41: 2195-2197, 2015. https://doi.org/10.1007/s00134-015-3918-7

HABERTHÜR C, SEEBERGER MD: Acute respiratory distress syndrome and mechanical ventilation: ups and downs of an ongoing relationship trap. J Thorac Dis 8: E1608-E1609, 2016. https://doi.org/10.1007/s00134-015-3918-7

HERRIDGE MS, MOSS M, HOUGH CL, HOPKINS RO, RICE TW, BIENVENU OJ, AZOULAY E: Recovery and outcomes after the acute respiratory distress syndrome (ARDS) in patients and their family caregivers. Intensive Care Med 42: 725-738, 2016. https://doi.org/10.1007/s00134-016-4321-8

HRAIECH S, YOSHIDA T, PAPAZIAN L: Balancing neuromuscular blockade versus preserved muscle activity. Curr Opin Crit Care 21: 26-33, 2015. https://doi.org/10.1097/MCC.0000000000000175

HUA Y, OU X, LI Q, ZHU T: Neuromuscular blockers in the acute respiratory distress syndrome: A meta-analysis. PLoS One 15: e0227664, 2020. https://doi.org/10.1371/journal.pone.0227664 
HUSSAIN M, XU C, AHMAD M, MAJEED A, LU M, WU X, TANG L, WU X: Acute respiratory distress syndrome: bench-to-bedside approaches to improve drug development. Clin Pharmacol Ther 104: 484-494, 2018. https://doi.org/10.1002/cpt.1034

KLOOT TE, BLANCH L, MELYNNE YOUNGBLOOD A, WEINERT C, ADAMS AB, MARINI JJ, SHAPIRO RS, NAHUM A: Recruitment maneuvers in three experimental models of acute lung injury. Effect on lung volume and gas exchange. Am J Respir Crit Care Med 161: 1485-1494, 2000. https://doi.org/10.1164/ajrccm.161.5.9809014

KOSUTOVA P, MIKOLKA P, BALENTOVA S, ADAMKOV M, KOLOMAZNIK M, CALKOVSKA A, MOKRA D: Intravenous dexamethasone attenuated inflammation and influenced apoptosis of lung cells in an experimental model of acute lung injury. Physiol Res 65 (Suppl 5): S663-S672, 2016. https://doi.org/10.33549/physiolres.933531

KOSUTOVA P, MIKOLKA P, BALENTOVA S, KOLOMAZNIK M, ADAMKOV M, MOKRY J, CALKOVSKA A, MOKRA D: Effects of phosphodiesterase 5 inhibitor sildenafil on the respiratory parameters, inflammation and apoptosis in a saline lavage-induced model of acute lung injury. J Physiol Pharmacol 69: 815-826, 2018a. https://doi.org/10.1183/13993003.congress-2018.PA5252

KOSUTOVA P, MIKOLKA P, KOLOMAZNIK M, BALENTOVA S, ADAMKOV M, CALKOVSKA A, MOKRA D: Reduction of lung inflammation, oxidative stress and apoptosis by the PDE4 inhibitor roflumilast in experimental model of acute lung injury. Physiol Res 67 (Suppl 4): S645-S654, 2018b. https://doi.org/10.33549/physiolres.934047

KUBA K, IMAI Y, RAO S, GAO H, GUO F, GUAN B, HUAN Y, YANG P, ZHANG Y, DENG W, BAO L, ZHANG B, LIU G, WANG Z, CHAPPELL M, LIU Y, ZHENG D, LEIBBRANDT A, WADA T, SLUTSKY AS, LIU D, QIN C, JIANG C, PENNINGER JM: A crucial role of angiotensin converting enzyme 2 (ACE2) in SARS coronavirus-induced lung injury. Nat Med 11: 875-879, 2005. https://doi.org/10.1038/nm1267

LEITE-JUNIOR JH, GARCIA CS, SOUZA-FERNANDES AB, SILVA PL, ORNELLAS DS, LARANGEIRA AP, CASTRO-FARIA-NETO HC, MORALES MM, NEGRI EM, CAPELOZZI VL, ZIN WA, PELOSI P, BOZZA PT, ROCCO PR: Methylprednisolone improves lung mechanics and reduces the inflammatory response in pulmonary but not in extrapulmonary mild acute lung injury in mice. Crit Care Med 36: 2621-2628, 2008. https://doi.org/10.1097/CCM.0b013e3181847b43

LI G, MALINCHOC M, CARTIN-CEBA R, VENKATA CV, KOR DJ, PETERS SG, HUBMAYR RD, GAJIC O: Eight-year trend of acute respiratory distress syndrome: a population-based study in Olmsted County, Minnesota. Am J Respir Crit Care Med 183: 59-66, 2010. https://doi.org/10.1164/rccm.201003-0436OC

LICHTENSTEIN DA, MEZIĖRE GA: Relevance of lung ultrasound in the diagnosis of acute respiratory failure: the BLUE protocol. Chest 134: 117-125, 2008. https://doi.org/10.1378/chest.07-2800

LIU C, LI JG: Role of genetic factors in the development of acute respiratory distress syndrome. J Transl Intern Med 2: 107, 2014. https://doi.org/10.4103/2224-4018.141831

LV X, WEN T, SONG J, XIE D, WU L, JIANG X, JIANG P, WEN Z: Extracellular histones are clinically relevant mediators in the pathogenesis of acute respiratory distress syndrome. Respir Res 18: 165, 2017. https://doi.org/10.1186/s12931-017-0651-5

MARSHALL RP, BELLINGAN G, WEBB S, PUDDICOMBE A, GOLDSACK N, MCANULTY RJ, LAURENT GJ: Fibroproliferation occurs early in the acute respiratory distress syndrome and impacts on outcome. Am J Respir Crit Care Med 162: 1783-1788, 2000. https://doi.org/10.1164/ajrccm.162.5.2001061

MATTHAY MA, WARE LB, ZIMMERMAN GA: The acute respiratory distress syndrome. J Clin Invest 122: 2731-2740, 2012. https://doi.org/10.1172/JCI60331

MEDURI GU, SIEMIENIUK RAC, NESS RA, SEYLER SJ: Prolonged low-dose methylprednisolone treatment is highly effective in reducing duration of mechanical ventilation and mortality in patients with ARDS. J Intensive Care 6: 53, 2018. https://doi.org/10.1186/s40560-018-0321-9

MEYER NJ, CALFEE CS: Novel translational approaches to the search for precision therapies for acute respiratory distress syndrome. Lancet Respir Med 5: 512-523, 2017. https://doi.org/10.1016/S2213-2600(17)30187-X 
MIKOLKA P, KOPINCOVÁ J, KOŠÚTOVÁ P, ČIERNY D, ČALKOVSKÁ A, MOKRÁ D: Lung inflammatory and oxidative alterations after exogenous surfactant therapy fortified with budesonide in rabbit model of meconium aspiration syndrome. Physiol Res 65 (Suppl 5): S653-S662, 2016. https://doi.org/10.33549/physiolres.933529

MIKOLKA P, KOSUTOVA P, KOLOMAZNIK M, TOPERCEROVA J, KOPINCOVA J, CALKOVSKA A, MOKRA D: Effect of different dosages of dexamethasone therapy on lung function and inflammation in an early phase of acute respiratory distress syndrome model. Physiol Res 68 (Suppl 3): S253-S263, 2019. https://doi.org/10.33549/physiolres.934364

MIKOLKA P, MOKRÁ D, KOPINCOVÁ J, TOMČÍKOVÁ-MIKUŠIAKOVÁ L, CALKOVSKÁ A: Budesonide added to modified porcine surfactant Curosurf may additionally improve the lung functions in meconium aspiration syndrome. Physiol Res 62 (Suppl 1): S191-S200, 2013. https://doi.org/10.33549/physiolres.932606

MILNE S, YANG CX, TIMENS W, BOSSÉ Y, SIN DD: SARS-CoV-2 receptor ACE2 gene expression and RAAS inhibitors. Lancet Respir Med 8: e50-e51, 2020. https://doi.org/10.1016/S2213-2600(20)30224-1

MOKRA D, DRGOVA A, MOKRY J, PULLMANN R, REDFORS B, PETRASKOVA M, CALKOVSKA A: Comparison of the effects of low-dose vs. high-dose aminophylline on lung function in experimental meconium aspiration syndrome. J Physiol Pharmacol 59 (Suppl 6): 449-459, 2008.

MOKRA D, DRGOVA A, PULLMANN R, CALKOVSKA A: Selective phosphodiesterase 3 inhibitor olprinone attenuates meconium-induced oxidative lung injury. Pulm Pharmacol Ther 25: 216-222, 2012. https://doi.org/10.1016/j.pupt.2012.02.007

MOKRA D, KOSUTOVA P, BALENTOVA S, ADAMKOV M, MIKOLKA P, MOKRY J, ANTOSOVA M, CALKOVSKA A: Effects of budesonide on the lung functions, inflammation and apoptosis in a saline-lavage model of acute lung injury. J Physiol Pharmacol 67: 919-932, 2016.

MOKRA D, KOSUTOVA P: Biomarkers in acute lung injury. Respir Physiol Neurobiol 209: 52-58, 2015. https://doi.org/10.1016/j.resp.2014.10.006

MOKRA D, MIKOLKA P, KOSUTOVA P, MOKRY J: Corticosteroids in acute lung injury: the dilemma continues. Int J Mol Sci 20: pii: E4765, 2019. https://doi.org/10.3390/ijms20194765

MOKRA D, MOKRY J, TONHAJZEROVA I: Anti-inflammatory treatment of meconium aspiration syndrome: benefits and risks. Respir Physiol Neurobiol 187: 52-57, 2013. https://doi.org/10.1016/j.resp.2013.02.025

MORTELLITI MP, MANNING HL: Acute respiratory distress syndrome. Am Fam Physician 65: 1823-1830, 2002.

NETO AS, PEREIRA VG, ESPÓSITO DC, DAMASCENO MC, SCHULTZ MJ: Neuromuscular blocking agents in patients with acute respiratory distress syndrome: a summary of the current evidence from three randomized controlled trials. Ann Intensive Care 2: 33, 2012. https://doi.org/10.1186/2110-5820-2-33

PEEK GJ, MUGFORD M, TIRUVOIPATI R, WILSON A, ALLEN E, THALANANY MM, HIBBERT CL, TRUESDALE A, CLEMENS F, COOPER N, FIRMIN RK, ELBOURNE D; CESAR TRIAL COLLABORATION: Efficacy and economic assessment of conventional ventilatory support versus extracorporeal membrane oxygenation for severe adult respiratory failure (CESAR): a multicentre randomised controlled trial. Lancet 374: 1351-1363, 2009. https://doi.org/10.1016/S0140-6736(09)61069-2

PELOSI P, D'ONOFRIO D, CHIUMELLO D, PAOLO S, CHIARA G, CAPELOZZI VL, BARBAS CS, CHIARANDA M, GATTINONI L: Pulmonary and extrapulmonary acute respiratory distress syndrome are different. Eur Respir J 22 (Suppl): 48s-56s, 2003. https://doi.org/10.1183/09031936.03.00420803

REILLY JP, BELLAMY S, SHASHATY MG, GALLOP R, MEYER NJ, LANKEN PN, KAPLAN S, HOLENA DN, MAY AK, WARE LB, CHRISTIE JD: Heterogeneous phenotypes of acute respiratory distress syndrome after major trauma. Ann Am Thorac Soc 11: 728-736, 2014. https://doi.org/10.1513/AnnalsATS.201308-280OC

ROCCO PR, PELOSI P: Pulmonary and extrapulmonary acute respiratory distress syndrome: Myth or reality? Curr Opin Crit Care 14: 50-55, 2008. https://doi.org/10.1097/MCC.0b013e3282f2405b

RUBENFELD GD, CALDWELL E, PEABODY E, WEAVER J, MARTIN DP, NEFF M, STERN EJ, HUDSON LD: Incidence and outcomes of acute lung injury. $\mathrm{N}$ Engl $\mathrm{J}$ Med 353: 1685-1693, 2005. https://doi.org/10.1056/NEJMoa050333

SAHARAN S, LODHA R, KABRA SK: Management of acute lung injury/ARDS. Indian J Pediatr 77: 1296-1302, 2010. https://doi.org/10.1007/s12098-010-0169-Z 
SALARI P, MOJTAHEDZADEH M, NAJAFI A, SADRAIE S, BAHAADINI K, MOHARRERI M, HADAVAND N, ABDOLLAHI M: Comparison of the effect of aminophylline and low PEEP vs. high PEEP on EGF concentration in critically ill patients with ALI/ARDS. J Clin Pharm Ther 30: 139-144, 2005. https://doi.org/10.1111/j.1365-2710.2004.00621.x

SEELEY EJ: Updates in the management of acute lung injury: a focus on the overlap between AKI and ARDS. Adv Chronic Kidney Dis 20: 14-20, 2013. https://doi.org/10.1053/j.ackd.2012.10.001

SEMLER MW, WHEELER AP, THOMPSON BT, BERNARD GR, WIEDEMANN HP, RICE TW; NATIONAL INSTITUTES OF HEALTH NATIONAL HEART, LUNG, AND BLOOD INSTITUTE ACUTE RESPIRATORY DISTRESS SYNDROME NETWORK: Impact of initial central venous pressure on outcomes of conservative versus liberal fluid management in acute respiratory distress syndrome. Crit Care Med 44: 782-789, 2016. https://doi.org/10.1097/CCM.0000000000001555

SHAVER CM, BASTARACHE JA: Clinical and biological heterogeneity in acute respiratory distress syndrome: direct versus indirect lung injury. Clin Chest Med 35: 639-653, 2014. https://doi.org/10.1016/j.ccm.2014.08.004

SCHICK MA, WUNDER C, WOLLBORN J, ROEWER N, WASCHKE J, GERMER CT, SCHLEGEL N: Phosphodiesterase-4 inhibition as a therapeutic approach to treat capillary leakage in systemic inflammation. J Physiol 590: 2693-2708, 2012. https://doi.org/10.1113/jphysiol.2012.232116

SILVA JD, DE CASTRO LL, BRAGA CL, OLIVEIRA GP, TRIVELIN SA, BARBOSA-JUNIOR CM, MORALES MM, DOS SANTOS CC, WEISS DJ, LOPES-PACHECO M, CRUZ FF, ROCCO PRM: Mesenchymal stromal cells are more effective than their extracellular vesicles at reducing lung injury regardless of acute respiratory distress syndrome etiology. Stem Cells Int 2019: 8262849, 2019. https://doi.org/10.1155/2019/8262849

SPADARO S, PARK M, TURRINI C, TUNSTALL T, THWAITES R, MAURI T, RAGAZZI R, RUGGERI P, HANSEL TT, CARAMORI G, VOLTA CA: Biomarkers for acute respiratory distress syndrome and prospects for personalised medicine. J Inflamm (Lond) 16: 1, 2019. https://doi.org/10.1186/s12950-018-0202-y

STANDIFORD TJ, WARD PA: Therapeutic targeting of acute lung injury and acute respiratory distress syndrome. Transl Res 167: 183-191, 2016. https://doi.org/10.1016/j.trsl.2015.04.015

STEINBERG KP, HUDSON LD, GOODMAN RB, HOUGH CL, LANKEN PN, HYZY R, THOMPSON BT, ANCUKIEWICZ M; NATIONAL HEART, LUNG, AND BLOOD INSTITUTE ACUTE RESPIRATORY DISTRESS SYNDROME (ARDS) CLINICAL TRIALS NETWORK: Efficacy and safety of corticosteroids for persistent acute respiratory distress syndrome. N Engl J Med 354: 1671-1684, 2006. https://doi.org/10.1056/NEJMoa051693

STRINGER KA, MCKAY RT, KARNOVSKY A, QUÉMERAIS B, LACY P: Metabolomics and its application to acute lung diseases. Front Immunol 7: 44, 2016. https://doi.org/10.3389/fimmu.2016.00044

SWEENEY RM, MCAULEY DF: Acute respiratory distress syndrome. Lancet 388: 2416-2430, 2016. https://doi.org/10.1016/S0140-6736(16)00578-X

THOMPSON BT, CHAMBERS RC, LIU KD: Acute respiratory distress syndrome. N Engl J Med 377: 562-572, 2017. https://doi.org/10.1056/NEJMra1608077

TONGYOO S, PERMPIKUL C, MONGKOLPUN W, VATTANAVANIT V, UDOMPANTURAK S, KOCAK M, MEDURI GU: Hydrocortisone treatment in early sepsis-associated acute respiratory distress syndrome: results of a randomized controlled trial. Crit Care 20: 329, 2016. https://doi.org/10.1186/s13054-016-1511-2

UMBRELLO M, FORMENTI P, BOLGIAGHI L, CHIUMELLO D: Current concepts of ARDS: A narrative review. Int J Mol Sci 18: pii: E64, 2016. https://doi.org/10.3390/ijms18010064

VISWAN A, GHOSH P, GUPTA D, AZIM A, SINHA N: Distinct metabolic endotype mirroring acute respiratory distress syndrome (ARDS) subphenotype and its heterogeneous biology. Sci Rep 9: 2108, 2019. https://doi.org/10.1038/s41598-019-39017-4

VISWAN A, SINGH C, RAI RK, AZIM A, SINHA N, BARONIA AK: Metabolomics based predictive biomarker model of ARDS: A systemic measure of clinical hypoxemia. PLoS One 12: e0187545, 2017. https://doi.org/10.1371/journal.pone.0187545

WANG Y, ZHONG M, WANG Z, SONG J, WU W, ZHU D: The preventive effect of antiplatelet therapy in acute respiratory distress syndrome: a meta-analysis. Crit Care 22: 60, 2018. https://doi.org/10.1186/s13054-018-1988-y 
WARE LB, MATTHAY MA: The acute respiratory distress syndrome. N Engl J Med 342: 1334-1349, 2000. https://doi.org/10.1056/NEJM200005043421806

WIEDEMANN HP, WHEELER AP, BERNARD GR, THOMPSON BT, HAYDEN D, DEBOISBLANC B, CONNORS AF JR, HITE RD, HARABIN AL; NATIONAL HEART, LUNG, AND BLOOD INSTITUTE ACUTE RESPIRATORY DISTRESS SYNDROME (ARDS) CLINICAL TRIALS NETWORK1: Comparison of two fluid-management strategies in acute lung injury. $\mathrm{N}$ Engl $\mathrm{J}$ Med 354: 2564-2575, 2006. https://doi.org/10.1056/NEJMoa062200

WILSON JG, LIU KD, ZHUO H, CABALLERO L, MCMILLAN M, FANG X, COSGROVE K, VOJNIK R, CALFEE CS, LEE JW, ROGERS AJ, LEVITT J, WIENER-KRONISH J, BAJWA EK, LEAVITT A, MCKENNA D, THOMPSON BT, MATTHAY MA: Mesenchymal stem (stromal) cells for treatment of ARDS: a phase 1 clinical trial. Lancet Respir Med 3: 24-32, 2015. https://doi.org/10.1016/S2213-2600(14)70291-7

XU Z, HUANG Y, MAO P, ZHANG J, LI Y: Sepsis and ARDS: The dark side of histones. Mediators Inflamm 2015: 205054, 2015. https://doi.org/10.1155/2015/205054

YOUNG D, LAMB SE, SHAH S, MACKENZIE I, TUNNICLIFFE W, LALL R, ROWAN K, CUTHBERTSON BH; OSCAR STUDY GROUP: High-frequency oscillation for acute respiratory distress syndrome. N Engl J Med 368: 806-813, 2013. https://doi.org/10.1056/NEJMoa1215716

ZHENG Z, JIANG L, ZHANG S, GUERVILLY C, ZHANG M, FENG X, DING J: Neuromuscular blocking agents for acute respiratory distress syndrome: an updated meta-analysis of randomized controlled trials. Respir Res 21 : 23, 2020. https://doi.org/10.1186/s12931-020-1287-4

ZHU Z, LIANG L, ZHANG R, WEI Y, SU L, TEJERA P, GUO Y, WANG Z, LU Q, BACCARELLI AA, ZHU X, BAJWA EK, TAYLOR THOMPSON B, SHI GP, CHRISTIANI DC: Whole blood microRNA markers are associated with acute respiratory distress syndrome. Intensive Care Med Exp 5: 38, 2017. https://doi.org/10.1186/s40635-017-0155-0 